\title{
デジタル画像相関法を用いたき裂背面からのパラメータ同定
}

\author{
西川 出 $^{* 1}$, 古川大介 ${ }^{* 2}$

\section{Estimation of Fracture Mechanics Parameter from Back Surface Strain Using Digital Image Correlation Method}

\author{
Izuru NISHIKAWA $^{* 1}$ and Daisuke FURUKAWA ${ }^{* 2}$ \\ *1 Osaka Institute of Technology, Dept. of Mechanical Engineering \\ 5-16-1, Ohmiya, Asahi-ku, Osaka, 535-8585 Japan
}

\begin{abstract}
Since an internal cracking often occurs at a piping in the nuclear power plant, nondestructive detection techniques of the crack are needed to maintain these plant. However, there is no effective method for crack detection method in the nuclear power plant.

In this study, we developed a new technique for estimation of fracture mechanics parameter from back surface of the crack using the digital image correlation method. It was found that the estimated stress intensity factor from back surface strain of the crack showed a good agreement with the applied stress intensity factor.
\end{abstract}

Key Words : Digital Image Correlation, Back Surface, Stress Intensity Factor, Crack

\section{1. 销豆}

機械構造物の破壊を防止するには，き裂の高精度検 出が重要である.このような要求に応える手法にはい くつかあるが, 原子カプラントに代表される高温水配 管のき裂に対して適応可能な方法は少ない. そこで, 本研究では，このような環境下でも使用可能な方法と して，画像処理を用いた手法の開発に取り組むことに した. 画像処理手法として, デジタル画像相関法(DCM) に注目し，これを用いてき裂背面からき裂を同定する システムの開発を試みた.

\section{2. デジタル国像相関法}

画像の相関判定には変形前後のサブセット（着目領 域) 内の画素の輝度值 $f, g$ の間で定義される相関係数 $S$ を用いた. この $S$ 值が最小となるサブセットの移動 先を Newton-Raphson 法により探索した.

変形前の座標 $(x, y)$ が変形により微小移動し変形後 の座標 $\left(x^{*}, y^{*}\right)$ 一移動するとき, これらの関係は次式で 表される. ここで $(u, v)$ は変形前後間の移動量の剛体移 動成分, $\Delta x, \Delta y$ は変形前画像でのサブセット中心か らの距離, $\partial u / \partial x, \partial v / \partial y$ はサブセットが一様変形す ると仮定したときの垂直ひずみ成分， $\partial v / \partial x ， \partial u /$

\footnotetext{
${ }^{* 1}$ 正員, 大阪工業大学 (T535-8585 大阪市旭区大宮 5-16-1) *2 学生員, 大阪工業大学大学院 工学研究科.

E-mail: nishikawa@med.oit.ac.jp
}

$$
\begin{gathered}
\partial y \text { はせん断ひずみ成分を表している. } \\
x^{*}=x+u+(\partial u / \partial x) \Delta x+(\partial u / \partial y) \Delta y \\
y^{*}=y+v+(\partial v / \partial x) \Delta x+(\partial v / \partial y) \Delta y
\end{gathered}
$$

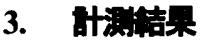

疲労予き裂を導入したアルミニウム試験片を用いて 引張試験を行い，き裂背面の変位分布を撮影した．座 標系は引張方向が $y$ 方向となるように設定した. 撮影 した画像のサイズは $640 \times 480[$ pixel]であり， 1 画素の 実視野寸法は $8.21[\mathrm{~mm} /$ pixel]である。

撮影した画像の中から変形前後の2枚の画像を選び， デジタル画像相関法を用いて，種々の $\Delta K$ に対して， ひずみ分布計測を行った.ひずみ $\varepsilon_{y}$ は二つの標点のy 方向変位差から求めた.

ひずみ分布計測の一例を図 1 に示す.ここではき裂 長さ $a=2.36[\mathrm{~mm}]$ の試験片を使用し, 変形前画像には $K=1[\mathrm{MPa} \sqrt{\mathrm{m}}]$,変形後画像には $K=5[\mathrm{MPa} \sqrt{\mathrm{m}}]$ で撮影し

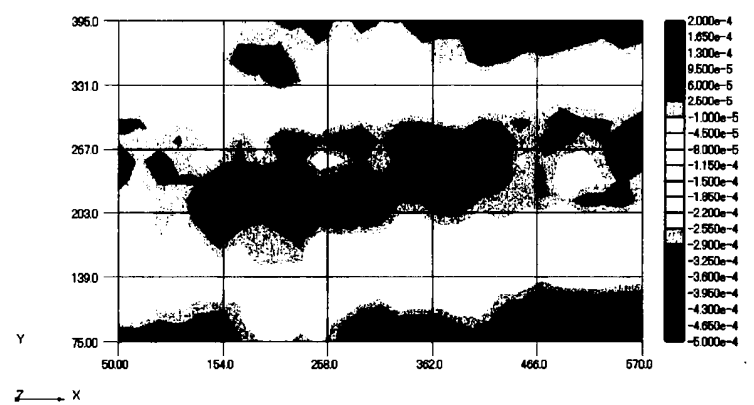

Fig.1 Distribution of back surface strain 
たものを用いた. すなわち応力拡大係数幅の設定值は $\Delta K=4[\mathrm{MPa} \sqrt{\mathrm{m}}]$ となる. ひずみ計測で得られた全評価 点に対して $\varepsilon=\alpha(y-\beta)^{2}+\gamma$ なる2次回帰を行った.

各き裂長さ $a$ に対する背面ひずみデータから得た回 㷌係数 $\alpha$ と応力拡大係数幅 $\Delta K$ の関係を図 2 に示した.

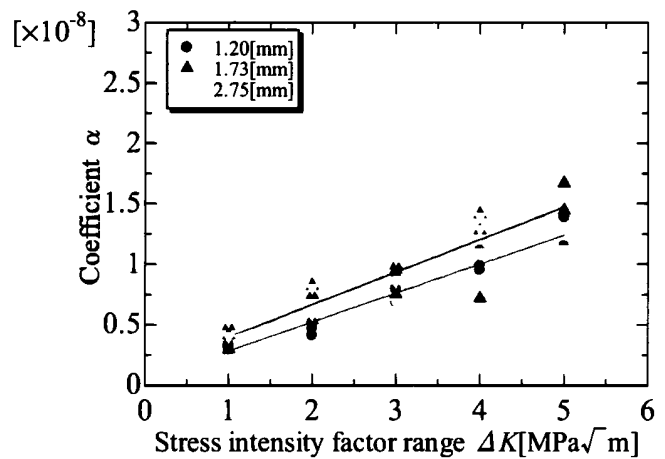

Fig.2 Relationship between coefficient $\alpha$ and stress intensity factor range $\Delta K$

この図から, 応力拡大係数 $\Delta K$ と係数 $\alpha$ との間には次の 関係があることがわかった。

$\Delta K=\alpha /\left(3.03 \times 10^{-9}\right)$

この式を用いて種々の設定応力拡大係数における 背面ひずみデータから応力桩大倸数を評価した結果を 図 3 に示した. 同図より，評価値は設定值と良く対応 していることがわかった.

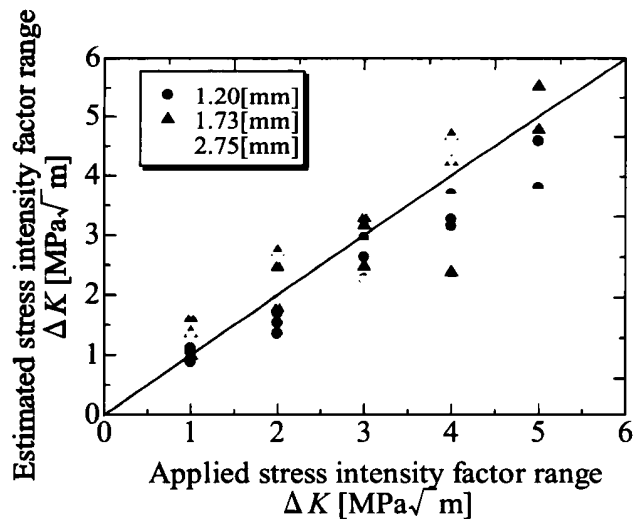

Fig.3 Relationship between applied and estimated stress intensity factor range

\section{4. 特具䭪デジタル僈像相関法}

次に，あらゆる計測対象に適用可能である，背面ひ ずみから応力拡大係数を評価する手法の開発を行った。

変形前後の画像における着目領域の微小移動を次 式で表現した.

$$
\begin{aligned}
& x^{*}=x_{1}+u-y_{t} \mathrm{R} \\
& y^{*}=y_{1}+v+v_{K}+x_{1} R
\end{aligned}
$$

式中の $x_{1} R, y_{\mathrm{t}} R$ は画像の剛体回転成分， $x_{0} ， y_{\mathrm{t}}$ はそれ ぞれき裂先端を原点とした時の計測点の $x, y$ 座標, $u$, $v$ は剛体移動成分， $v_{K}$ はき裂によって生じる変位成分 であり，次式の通りである.

$$
v_{K}=r^{1 / 2} /\left\{2 G(2 \pi)^{1 / 2}\right\}\left[K_{\mathrm{I}}\{(\kappa+0.5) \sin 0.5 \theta-0.5 \sin 1.5 \theta\}\right.
$$

$\left.-K_{\Pi}\{(\kappa-1.5) \sin 0.5 \theta+0.5 \cos 1.5 \theta\}\right]$

式中の $G$ は横弾性係数, $K_{\mathrm{I}}, K_{\mathrm{I}}$ は応力抗大係数で ある.この特異場デジタル画像相関法を用いてき裂背 面から応力拡大係数評価を行った. $x$ 方向の計測範囲 は $x=100[$ pixel] から $x=540[$ pixel] である.き裂長さ $a=1.65[\mathrm{~mm}]$ における応力拡大係数評価の結果を図 4 に き裂長さ $a=2.36[\mathrm{~mm}]$ における応力拡大倸数評価の結 果を図 5 に示寸。

図4より $\Delta K=2[\mathrm{MPa} \sqrt{\mathrm{m}}]$ においては概ね良好な評価 結果が得られた. しかし， $\Delta K=4[\mathrm{MPa} \sqrt{\mathrm{m}}], \Delta K=5[\mathrm{MPa}$ $\sqrt{\mathrm{m}]}$ に関しては設定值から大きく外れる結果となっ た。 また，図 5 では，おおむね良好な評価結果が得ら れていることがわかる. 特に $\Delta K=1[\mathrm{MPa} \sqrt{\mathrm{m}}]$ から $\Delta$ $K=3[\mathrm{MPa} \sqrt{\mathrm{m}}]$ の範囲において良好な結果が得られた.

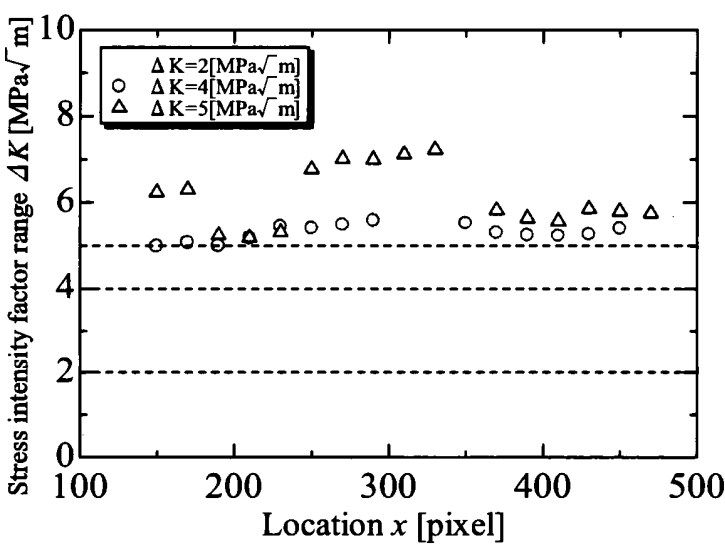

Fig.4 Evaluation of stress intensity factors (Crack length $a=1.65 \mathrm{~mm}$ )

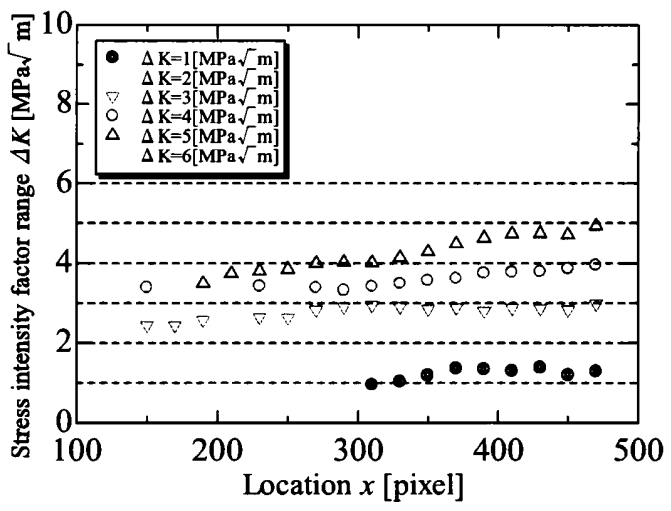

Fig.5 Evaluation of stress intensity factors (Crack length $a=2.36 \mathrm{~mm}$ )
5. 結百 略 